\title{
Geographical and seasonal distribution of the coconut mite, Aceria guerreonis (Acari: Eriophyidae), in Puerto Rico and Florida, USA ${ }^{1,2}$
}

\author{
Forrest W. Howard," Edwin Abreu-Rodriguez," and \\ Harold A. Denmark.
}

\begin{abstract}
The coconut mite, Aceria guerreronis Keifer, was collected for the first time in Puerto Rico in 1977. It was reported for the first time in Florida in 1984 , although it may have been present in the state since the 1950s. On the basis of damage symptoms observed during 1986-87, the coconut mite was distributed in almost all plantings of coconut in Puerto Rico. The percentage of trees with symptoms was highest on the west coast, where planting density is highest. During the same periad, the percentage of coconut palms infested with coconut mites varied from 66 to $98 \%$ at different sites on the Florida Keys. On the Florida mainland, the percentage of trees with coconut mite damage was usually less than $7 \%$. At several sites on the Florida mainland revisited in 1988, coconut mites had spread locally. At Playa Tres Hermanos in Añasco, Puerto Rico, and Bahía Honda Key, Florida, where monthly sampling was conducted, coconut mite population fluctuations did not appear to be strongly associated with dry and wet periods or mean daily temperatures.

A list of mite species associated with the coconut mite was reported. It included four species reported for the first time in Puerto Rico.

In Puerto Rico, Bdella distincta preyed on both coconut mite and Steneotarsonemus furcatus. In Florida, Amblyseius largoensis, Neoseiulus mumai, and $\boldsymbol{N}$. paspalivorus were observed preying on coconut mites. However, these predators apparently do not significantly affect coconut
\end{abstract}

'Manuscript submitted to Editorial Board 2 August 1989.

${ }^{2}$ Authors thank David Maloney and Alfredo Acevedo for valuable assistance throughout this work. Jim DeFilippis assisted in field work and provided fig. 2. Dr. Gregory Erdos, Department of Microbiology and Cell Science, University of Florida, provided fig. 1. Dr. George Oldfield, U. S. Department of Agriculture, contributed interesting ideas which improved our study. Drs. Robbin Giblin-Davis and Nigel Harrison reviewed the manuscript. This is Florida Department of Agriculture and Consumer Services, Bureau of Entomology, Contribution No. 706 and Florida Agriculture Experiment Station Journal Series No. 9927. This work was supported by a USDA special grant in Tropical Agriculture, \#85-CRSR-2-2574.

${ }^{3}$ University of Florida, IFAS, Fort Lauderdale Research \& Education Center, 3205 College Avenue, Fort Lauderdale, Florida 33314.

${ }^{A}$ Assistant Researcher, University of Puerto Rico, Agricultural Experiment Station, P. O. Box 417, Isabela, Puerto Rico 00662.

"Florida Department of Agriculture and Consumer Services, Division of Plant Industry, P. O. Box 1269, Gainesville, Florida 32602. 
mite populations. Tarsonemus sp. inflicted damage on the coconut similar to that caused by the coconut mite. Coconut mites beneath tepals of coconuts exposed to $-1.5^{\circ} \mathrm{C}$ for 5.5 hours were not affected adversely by this treatment. Some eggs remained viable after exposure to $-3^{\circ} \mathrm{C}$ up to 5 hours. Coconut mites survived at $5^{\circ} \mathrm{C}$ for 10 days. Thus, coconut mites are capable of surviving most winters on the Florida mainland.

\section{RESUMEN}

Distribución geográfica y estacional del ácaro del coco en Puerto Rico y Florida

El ácaro del coco, Aceria guerreronis Keifer, se encontró por primera vez en Puerto Rico en 1977; se regisłró por primera vez de Florida en 1984, aunque pudo haber esłodo presente desde la década de los 50 . Según los síntomas de los daños observados en 1986-87, el ácaro del coco estaba distribuido en casi todos los cocoteros en Puerto Rico. El porcentaje de las palmas con los síntomas fue más alto en la costa occidental, donde la densidad de la plantación fue más alta. Durante el mismo período, el porcentaje de cocoteros infestados con este ácaro varió de 66 a $98 \%$ en diferentes sitios en los cayos de Florida. En la tierra firme de Florida, el porcentaje de las palmas con daños del ácaro usualmente fue menos de $7 \%$. En varios sitios en la tierra firme de Florida, los cuales se volvieron a visitar en el 1988, la distribución del ácaro del coco se había extendido. En playa Tres Hermanos, Puerto Rico, y Cayo Bahía Honda, Florida, se hizo un muestreo mensual de los ácaros; las fluctuaciones de poblaciones no parecían estar asociadas ni con los períodos de sequía ni con los períodos de lluvia, ni aumentaron con relación a las altas temperaturas del verano. Se presenta una lista de los ácaros asociados con el ácaro del coco en ambas localidades y se informan por primera vez cuatro especies para Puerto Rico. En Puerto Rico, Bdella distincta se encontró alimentándose del ácaro del coco y de Steneofarsonemus furcafus. En Florida, se observaron Amblyseius largoensis, Neoseiulus mumai y $N$. paspalivorus depredando el ácaro del coco. Estos depredadores aparentemente no afectaron significativamente las poblaciones del ácaro. Tarsonemus sp. aparentemente causó daños semejantes al ácaro del coco en la etapa inicial de infestación. A los ácaros del coco debajo de los tépalos del coco expuestos a $-1.5^{\circ} \mathrm{C}$. por 5.5 horas aparentemente no los afectó adversamente este tratamiento. Unos huevos permanecieron viables después de estar expuestos a $-3^{\circ} \mathrm{C}$ por 5 horas. Los ácaros sobrevivieron a $5^{\circ} \mathrm{C}$ por 10 días. Esto demostró que el ácaro es capaz de sobrevivir la mayoría de los inviernos en Florida.

\section{INTRODUCTION}

Coconut, Cocos nucifera L., is one of the most important world crops. Although neither Puerto Rico nor Florida is a major coconut producer, the coconut palm is important in both localities. In Puerto Rico, where coconuts are sold mostly at fresh market, 9.8 million coconuts valued at $\$ 1.2$ million were harvested in fiscal year 1986-87 (13). In both Florida and Puerto Rico, where tourism is a major industry, coconut palms are an essential part of the tropical landscape.

The coconut mite, Aceria guerreronis Keifer (fig. 1), is a pest of coconuts that infests young developing tissue beneath the tepal, causing scarring and distortion of the nut with resulting loss of copra (fig. 2). In Puerto Rico, damaged coconuts are often rejected from fresh market 


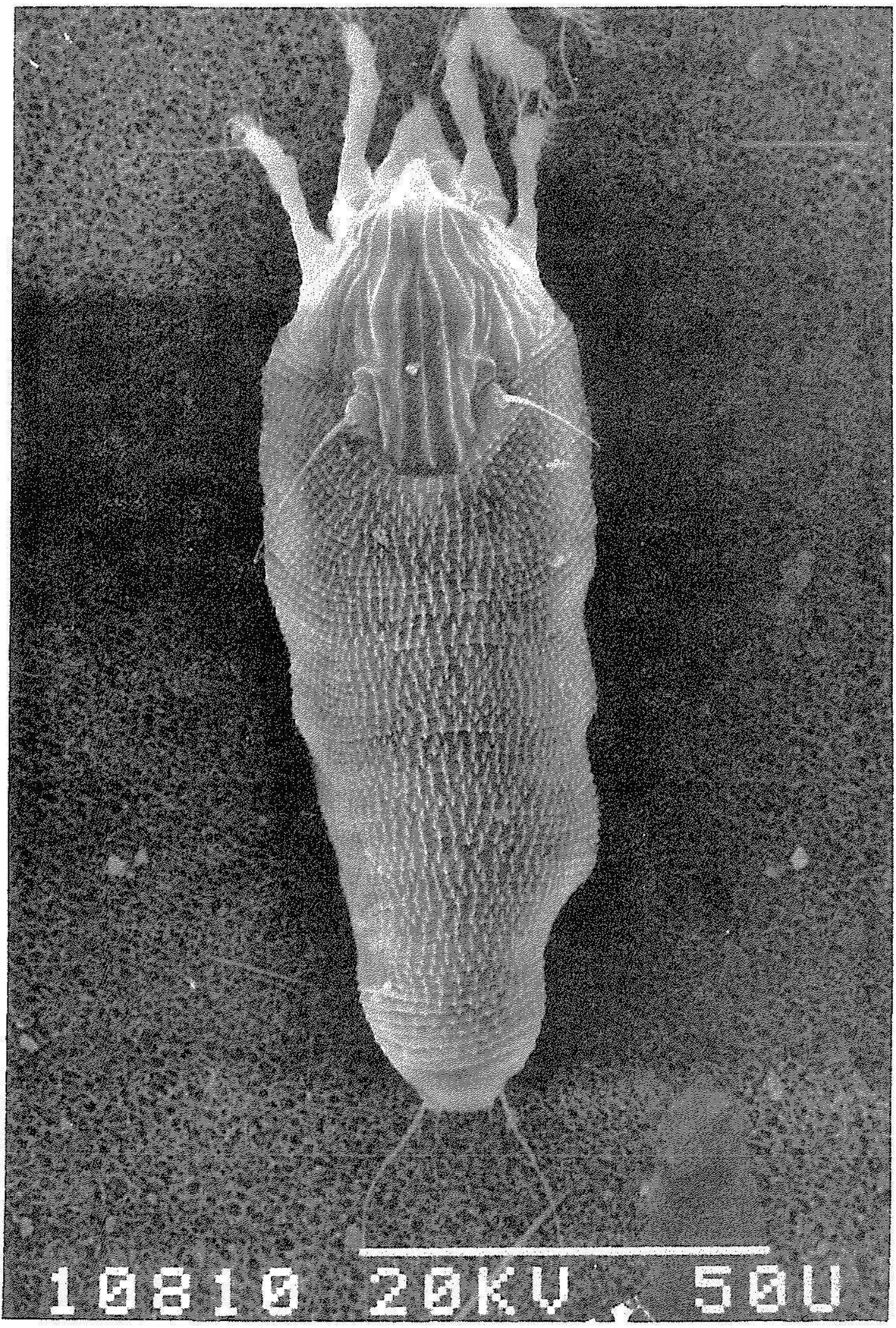

FIG. 1.-Scanning electron micrograph of the coconut mite, Aceria guerreronis. Line represents 50 microns. 


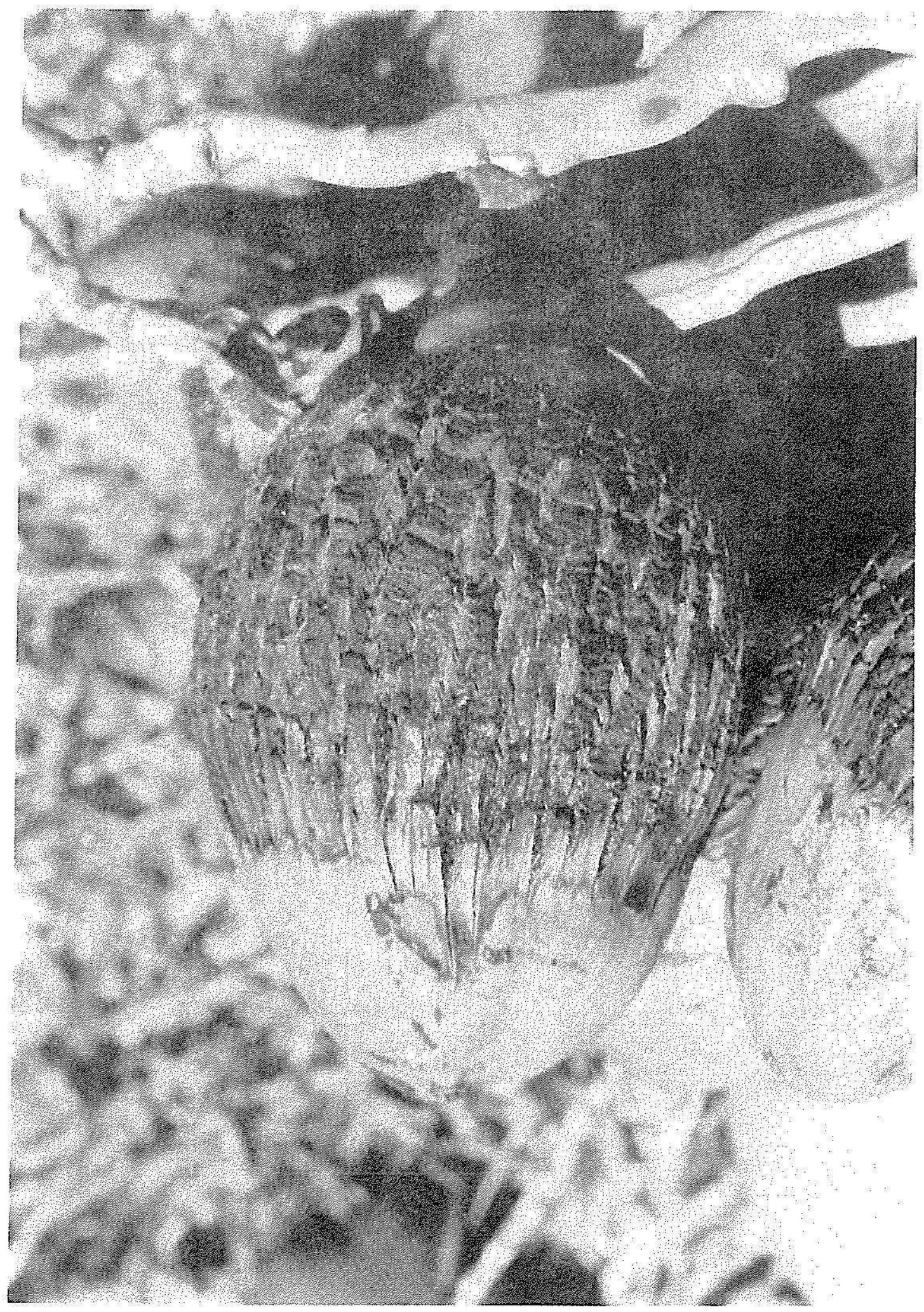

FIG. 2.-Coconuts damaged by coconut mites. a) old damage;

produce. In addition, damage due to these mites detracts from the ornamental value of palms. 


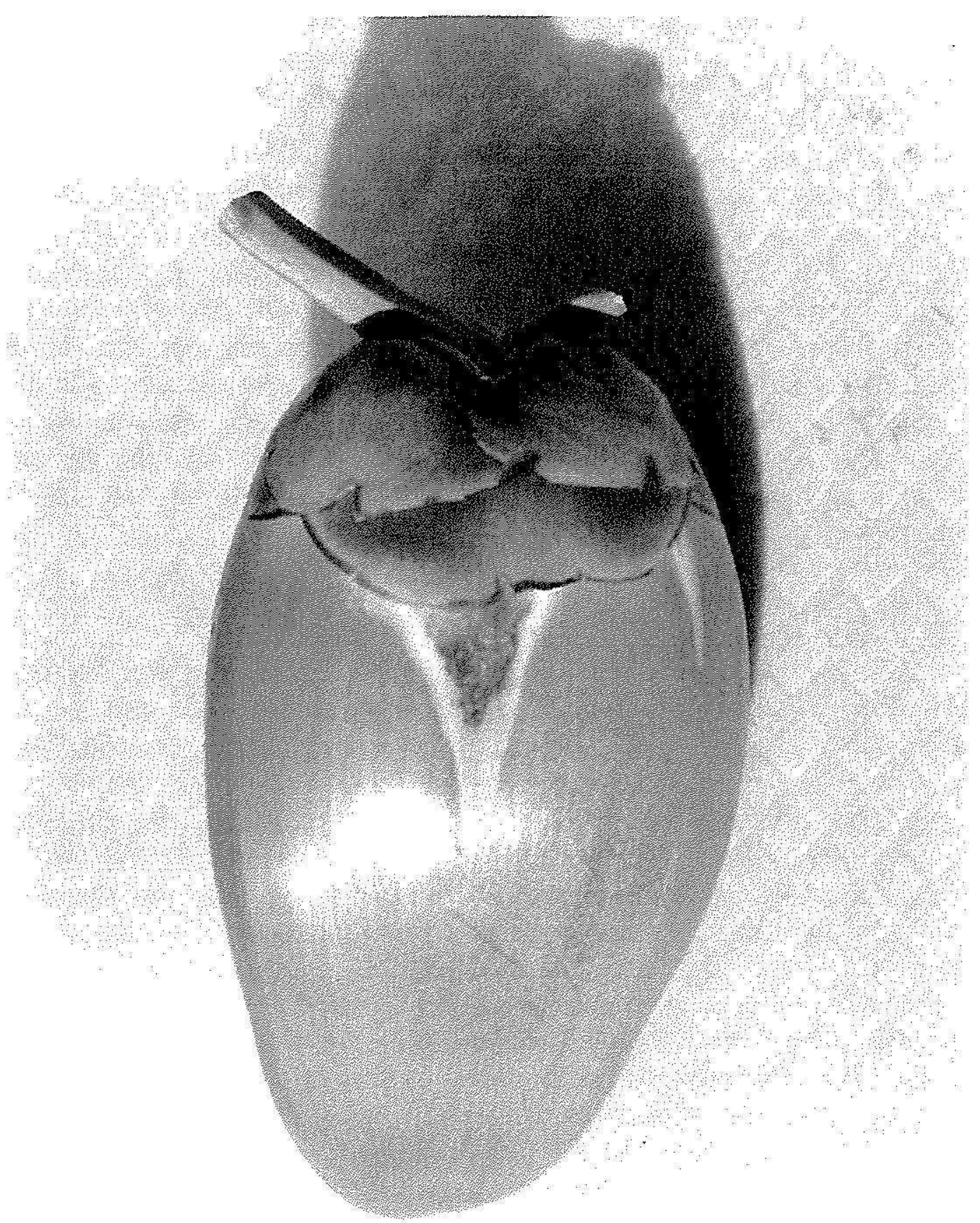

FIG. 2. b) early damage

In recent decades, coconut mites have been spreading from an undertermined original source, and are now reported from many countries of 
the Caribbean and West Africa $(3,5,9,14)$. The species was found for the first time in Puerto Rico in Loíza (just east of San Juan) in 1977 (12). This species was positively identified for the first time in the Continental United States by H. A. Denmark in March 1984 from specimens collected by F. W. Howard from coconuts on Sugarloaf Key, Florida. At that time, coconut mite damage on coconut palms was common on the Florida Keys.

There is a need for knowledge of the biology and ecology of the coconut mite in order that economically feasible and environmentally sound control methods may be developed. The objectives of the present study were to compare the geographical distribution, levels of infestation, and seasonal population fluctuations of the coconut mite in a tropical country, Puerto Rico, and in Florida, which is at the northern limit of the range of coconut palms. Another objective was to identify major ecological factors which influence populations of the mite and affect its distribution.

\section{MATERIALS AND METHODS}

Sites throughout the cultivated range of coconuts in Puerto Rico and Florida were visited in 1986-87. Our earlier observations had indicated that palms infested with coconut mites usually remain infested. Therefore, the percentage of coconuts infested at a particular site may increase over time. The percentage infested does not fluctuate during the year at a particular locality. Sites in Florida with incipient infestations of coconut mites in 1987 were re-examined in 1988. Bearing palms at these sites were selected at random and the coconuts examined. The coconuts of at least 15 palms were examined at each site, and up to 100 at sites with extensive plantings. We used binoculars to examine coconuts of the taller palms. Palms were classified as damaged by coconut mites if at least one coconut on the tree bore scars typical of the mite, and undamaged if no scars were seen. Occasionally, coconuts with scars were sampled and examined microscopically in the laboratory to confirm the presence of the coconut mite. Voucher specimens were kept for each new county record in Florida and for diverse localities in Puerto Rico.

To determine the seasonal population fluctuations of coconut mites, we sampled coconuts at Playa Tres Hermanos in Añasco, Puerto Rico, and Bahía Honda Key, Florida, because of accessibility and relatively large plantings.

Playa Tres Hermanos, on the west end of Puerto Rico, is a public beach and site of an old coconut plantation. There were about 3,000 coconut palms, most of which had trunk heights of about $30 \mathrm{~m}$. We were equipped with an 8-m ladder; thus palms of 5- to 8-m trunk height were selected for study. From April 1986 to April 1988 five coconuts of $5-7 \mathrm{~cm}$ were selected monthly at random from each of 10 randomly selected palms with 5- to 8-m trunk height. 
Bahía Honda Key is a public park on the Florida Keys. There were about 120 coconut palms, most of which had trunk heights of about 8-10 $m$ in a planting on the southwest end of the key. Sampling methods were similar to those employed at Playa Tres Hermanos, except that instead of selecting palms at random each month, we randomly selected 10 palms in each of two groups at the beginning of the experiment in December 1985. Sampling was conducted monthly, alternating between the two groups, so that coconuts were removed from each sample palm every two months until December 1987.

Coconuts sampled at both localities were taken to the laboratory. The tepals were removed, the surface beneath them was examined with a stereozoom microscope, and the number of coconut mites on the surface of each coconut determined. Since coconut mites occur on coconut surfaces in aggregated "colonies," numbers per fruit greater than 1,000 were estimated by counting the number of mites in an area of $1 \mathrm{~mm}^{2}$ for each $25 \mathrm{~mm}^{2}$ of area occupied by coconut mites, calculating the mean number of mites per $\mathrm{mm}^{2}$ and multiplying by the total $\mathrm{mm}^{2}$ occupied by the "colony." Specimens of mites other than the coconut mite were collected and mounted on microscope slides and identified. We observed microscopically the species belonging to taxa known to be predaceous to determine whether they preyed on coconut mites.

Daily precipitation was recorded at the Mayagüez Airport, which is about $7 \mathrm{~km}$ from Playa Tres Hermanos. We obtained temperature and precipitation data at a weather station on Conch Key, Florida, $40 \mathrm{~km}$ from Bahía Honda Key, from the National Oceanographic and Atmospheric Sciences Administration.

During the course of this study, damage due to coconut mites was observed more frequently on palms on the Florida Keys than on the Florida mainland. We suspected that the distribution of coconut mite could be limited by cooler winter temperatures on the mainland. Data from stations in the southern coastal area of the Florida Peninsula of the National Weather Service over a 30-year period (1941-1970) revealed that the temperature dropped to $0^{\circ} \mathrm{C}$ a total of 25 times (i.e., once to a few times per year) and to about $-2^{\circ}$ a total of 10 times. The duration of these frosts was highly variable at different locations and in different years, but a temperature of $0^{\circ}$ or less for 4 hours could be considered typical. Temperatures of $-2^{\circ} \mathrm{C}$ or colder usually lasted 1 hour or less (6). In contrast, freezes are unknown on the Florida Keys. The temperature has not reached $0^{\circ} \mathrm{C}$ at Key West since the National Weather Service began keeping records there in 1870 . The minimum temperature of $5.0^{\circ}$ C was reached once in 1886 and once in 1981 (Dennis Henize, National Weather Service, Key West, Personal Communication).

Experiments were conducted to determine whether coconut mite populations could survive temperatures typical of frosts that occur in the southeast coastal area of Florida. 
To determine the effects of freezing temperatures on coconut mites in their natural habitat (i.e., beneath coconut tepals), we collected eight coconuts 7 to $11 \mathrm{~cm}$ long with coconut mite damage from palms in Miami and placed them in plastic bags in a temperature control cabinet at $-1.5^{\circ}$ $\pm 0.5^{\circ} \mathrm{C}$ for 5.5 hours. These were then kept at $+7^{\circ} \mathrm{C}$ for 72 hours, after whch time the tepals were removed and the coconut mites, if present, examined under a stereoscopic microscope.

To determine the effects of freezing on the viability of coconut mite eggs, we cut the inner tepal surface of a young coconut with coconut mites and their eggs into three pieces and removed the mites, leaving $40+$ eggs per piece. We held two pieces at $-3^{\circ} \pm 0.5^{\circ} \mathrm{C}$, one for $150 \mathrm{~min}$ and the other for $300 \mathrm{~min}$. After the cold treatment, these were removed to $25^{\circ} \mathrm{C}$. The third piece was held at ca $25^{\circ} \mathrm{C}$. We observed the eggs daily for 2 days.

To determine whether coconut mites could survive extended cool periods, we collected 4 coconuts with coconut mite damage from palms in Miami, wrapped them in plastic bags, and kept them in a refrigerator at ca $5^{\circ} \mathrm{C}$ for 10 days, after which time we removed the tepals and examined the coconuts under the microscope for coconut mites.

\section{RESULTS AND DISCUSSION}

On the basis of damage symptoms, the coconut mite was distributed on almost all plantings of coconut palms in Puerto Rico, most of which are in the coastal zone (fig. 3). On the west end of the island between Isabela and Boquerón, the mean percentage of palms infested at 15 sites was $71.6 \%$. In contrast, at 5 sites on the northern coast within $25 \mathrm{~km}$ of Arecibo, the mean percentage of infested palms was $22.4 \%$ (fig. 4). Plantings are less dense in this area than on the more westerly end; thus the infestation level is lower.

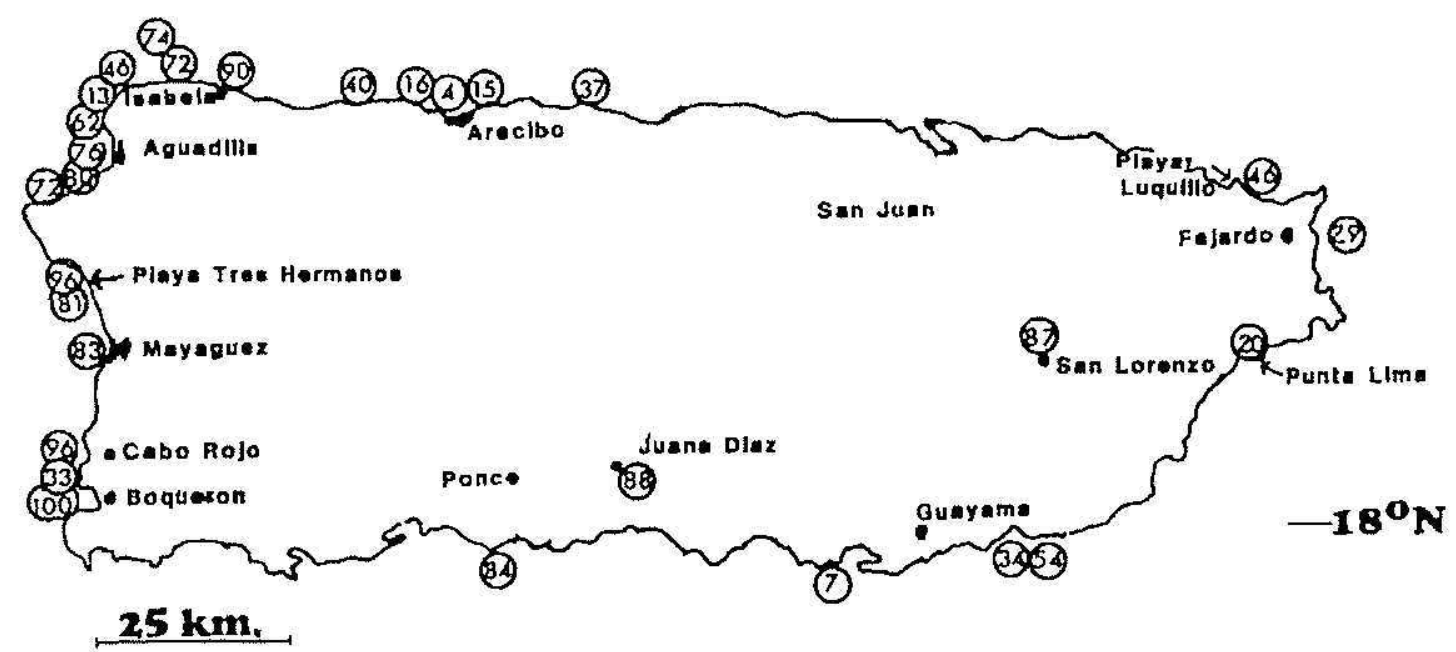

FIG. 3.-Distribution of coconut mites in Puerto Rico 1986-1987. Numbers in circles indicate the percentage of coconut palms infested at localities examined. 


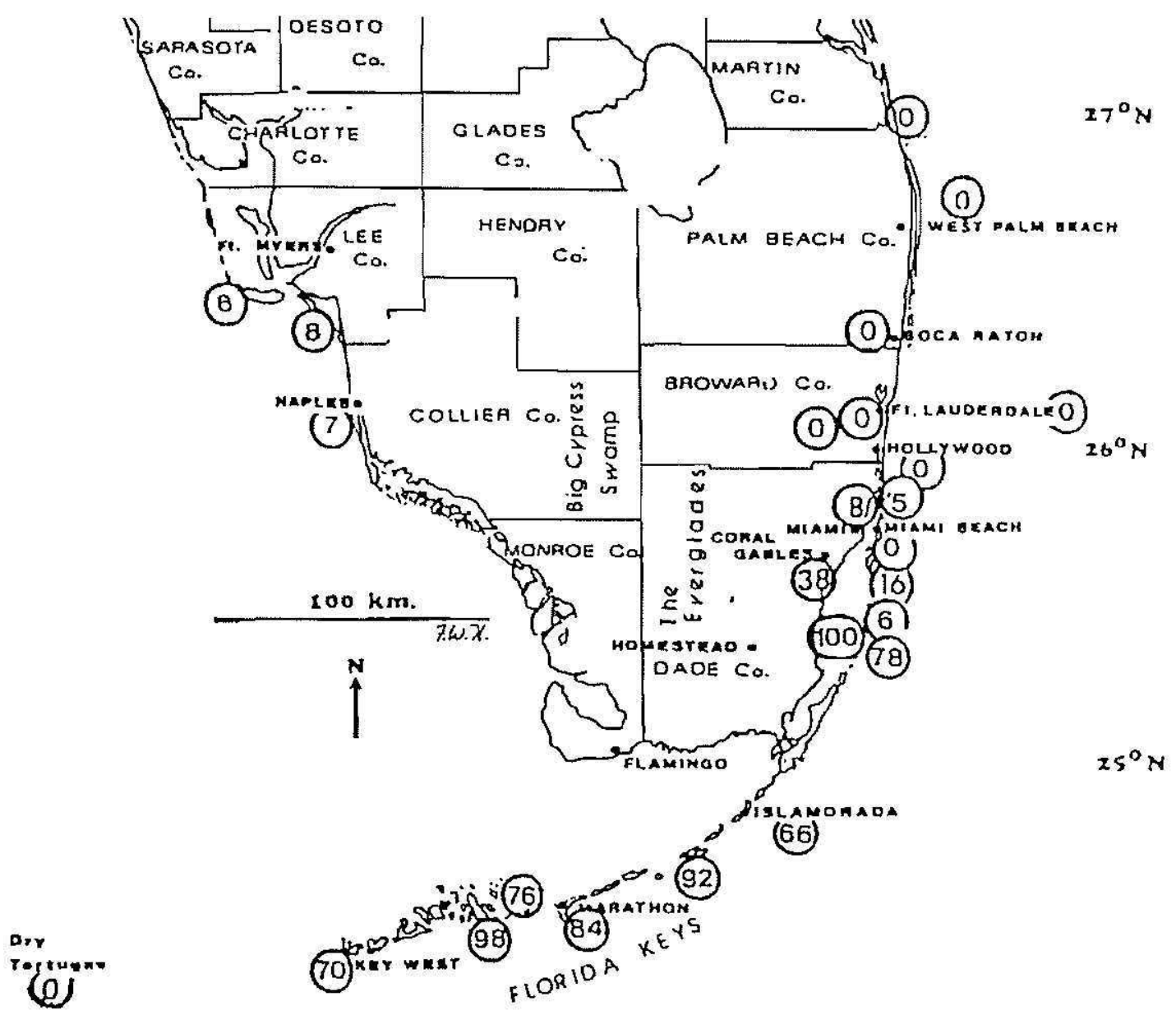

FIG. 4.-Distribution of coconut mites in Florida, 1986-1987. Numbers in circles indicate the percentage of coconut palms infested at localities examined.

In Florida, during 1986-1987 the percentage of coconut palms infested varied from $66.0 \%$ to $98.0 \%$ at different sites on the Florida Keys between Key West and Elliott Key (fig. 4). Relatively few coconut palms (5.5\%) on Boca Chica Key at the northeastern end of the Florida Keys archipelago and on barrier islands to the north (e.g., Miami Beach) were infested. High percentages of infested coconut palms were observed on the mainland at two localities: the Miami Coconut Seed Orchard (38.2\%) and the Biscayne National Park Headquarters on the west shore of Biscayne Bay near Homestead (100\%). Elsewhere on the Florida east coast, coconut mite damage was very infrequent. At three sites on the Florida west coast from Naples to Ft. Myers a mean of $7.0 \%$ of the coconuts examined were infested with coconut mites. From the road, using binoculars, we observed coconut mite damage on a group of three coconut palms that were on an inaccessible property in Ft. Lauderdale.

We visited repeatedly several sites in Florida and found that coconut mites had spread locally. We observed coconut damage on one palm during intensive searches on Key Biscayne in April and September 1985. In 
December 1987, the number of infested palms had increased to 18 . These infested palms were concentrated in a group near the originally infested palm, and another group at the southern tip of the island. Only one of the 175 palms at Haulover Beach examined in March 1987 had coconut mite damage. Nine months later (December 1987), six coconut palms, including five adjacent to the originally infested palm and one palm elsewhere in the planting, were infested. One year later (December 1988) the infestation was limited to the same palms.

At the Miami Coconut Seed Orchard, coconut mite damage was first observed on 5 palms in October 1985 (W. F. Theobald, Florida Division of Forestry, Personal Communication). The palms with coconut mite damage increased to $38 \%$ of 335 palms in April 1987 and $99.2 \%$ of 250 palms in December 1988. The rapid spread of coconut mites here compared to that of the former two localities may have been due to the relatively high planting density of palms at the Miami Seed Orchard.

At Playa Tres Hermanos, following a relatively rainy May 1986, the number of mites per infested coconut peaked in June and July, after which time they declined. The numbers of mites increased again in April 1987, a relatively rainy month that followed four dry winter months. Another peak occurred in October 1987, the rainiest month of the study period (fig. 5). At Bahía Honda, the numbers of coconut mites per infested coconut decreased from January through May 1986, during which time daily average temperatures increased; then the numbers increased at each sampling period and peaked in September after a relatively rainy August. The numbers then decreased until March 1987, then again increased at each sampling period, and peaked in November, a relatively cool month, during a relatively rainy three-month period (fig. 6). Thus, there was no indication that numbers of mites per infested coconuts per tree increased during dry weather as reported in some localities $(9,16)$, and there was no clear association of numbers of coconut mites per infested coconuts and mean daily temperatures, as might be expected.

There was a tendency for the percentage of infested coconuts per tree to vary with the mean number of mites per infested coconut, a relationship that was particularly clear at Bahia Honda Key.

Table 1 presents the species of mites that were found on coconut surfaces beneath tepals and living in the presence of coconut mites.

The mites Lasioseius sp., N. baraki, S. furcatus and B. distincta are reported for the first time in Puerto Rico.

In Puerto Rico, $B$. distincta preyed on both coconut mite and $S$. furcatus. In Florida, $A$. largoensis, $N$. mumai and $N$. paspalivorus were observed preying on coconut mites. Predaceous species of mites occurred occasionally and in low numbers under tepals of sampled coconuts, and had no significant impact on the coconut mite. These observations are similar to those of several authors, who reported that various species of 


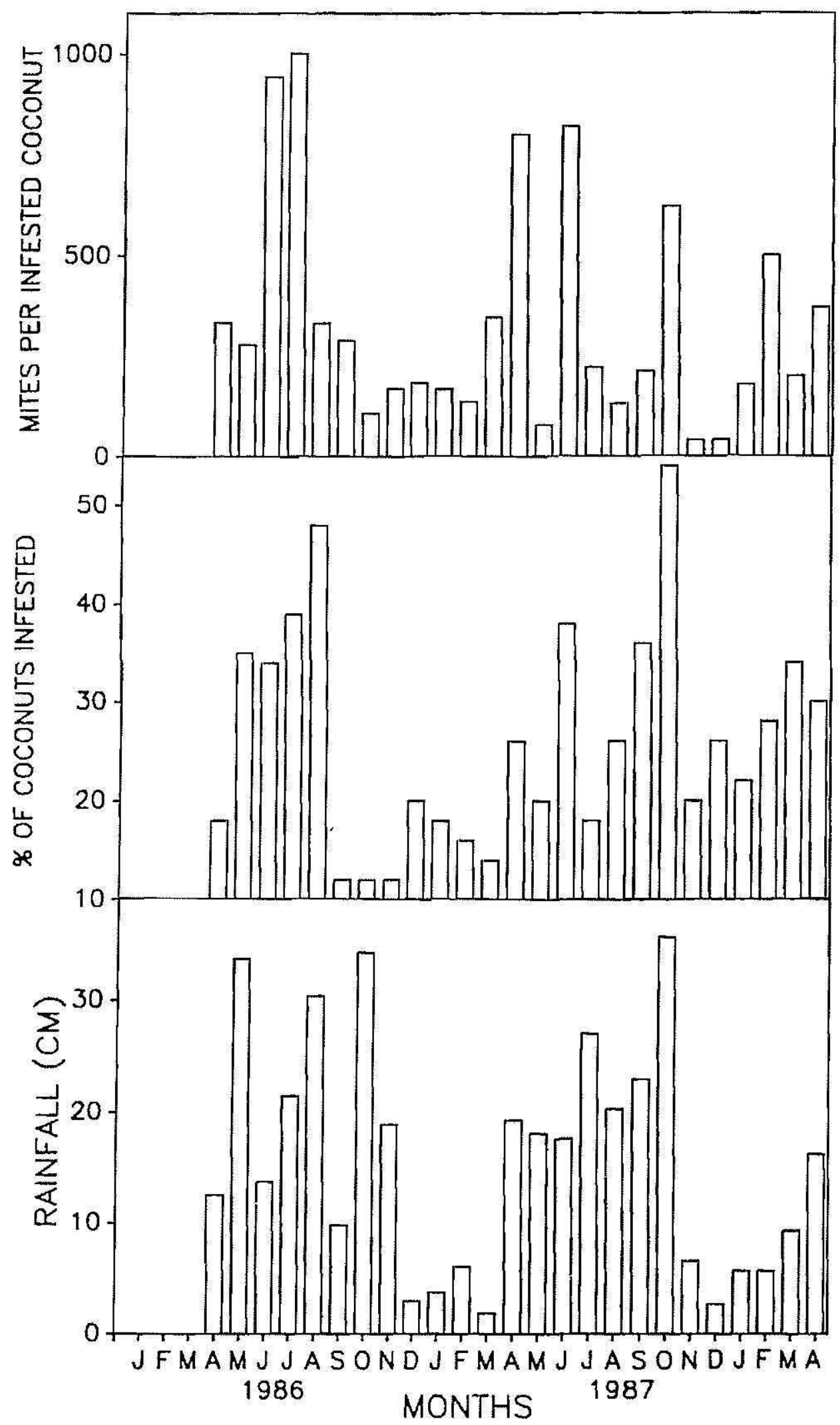

FIG. 5.-Coconut mite population fluctuations at Playa Tres Hermanos and precipitation at Añasco, Puerto Rico, April 1986-April 1988, showing mean percentage of coconuts infested per tree per month, mean numbers of coconut mites per infested fruits from ten sampled trees, and the monthly precipitation. 


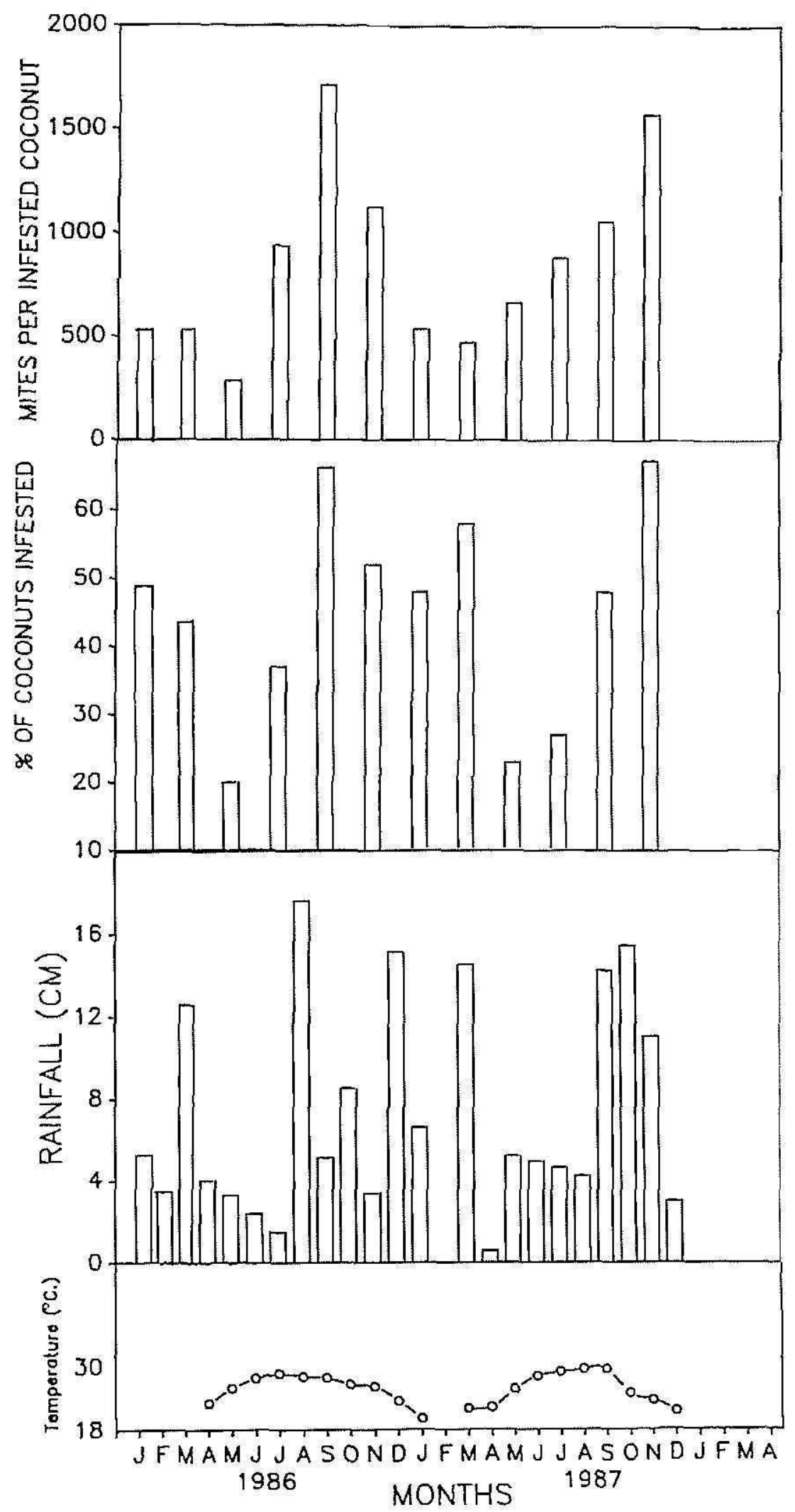

FIG. 6.-Coconut mite population fluctuations at Bahia Honda Key and weather data from Conch Key, Florida, January 1986-December 1988, showing the mean percentage of coconuts infested and the mean numbers of mites per infested coconut per 2-month period, the mean monthly temperatures and the total monthly precipitation. 
TABLE 1.-Mites associated with the coconut mite beneath bracteoles of coconut in Florida and Puerto Rico

\begin{tabular}{lll}
\hline Family & \multicolumn{1}{c}{ Mite Species } & Locality \\
\hline Phytoseiidae & Amblyseius largoensis (Muma) & Florida \\
Phytoseiidae & Neoseiulus mumai (Denmark) & Florida \\
Phytoseiidae & N. paspalivomis (De León) & Florida \\
Phytoseiidae & N. baraki Athias-Henriot & Puerto Rico \\
Tarsonemidae & Tarsonemus sp. & Florida, Puerto Rico \\
Tarsonemidae & Rhyncholarsonemus sp. & Florida \\
Tarsonemidae & Steneolarsonemus furcatus (De León) & Puerto Rico \\
Acaridae & Tyrophagus putrescentiae (Scrank) & Florida \\
Tydeidae & Tydeus sp. & Puerto Rico \\
Bdellidae & Bdella distincta (Bake \& Balogh) & Puerto Rico \\
Ascidae & Lasioseius sp. & Puerto Rico \\
\hline
\end{tabular}

predaceous mites in different countries attack coconut mites but apparently have little effect on populations $(2,5,9)$.

The most common mite found under coconut tepals in Puerto Rico was $S$. furcatus. This species has been associated with the coconut mite in Trinidad (14), but in this study it was found on coconuts with and without coconut mites.

Tarsonemus sp. was occasionally found on coconuts from Bahía Honda and localities in Puerto Rico associated with damage similar to that caused by the coconut mite. The damage consisted of a slightly darkened patch on the whitish coconut surface beneath the tepal that extended distally into the hardened green surface. Usually one to several hundred Tarsonemus sp. were distributed in this area and coconut mites were usually absent. Thus the damage was apparently due to the Tarsonemus $\mathrm{sp}$. So far we have observed this damage only on young coconuts (fig. 2b). It is not known how this damage develops as the coconut grows, but presumably it is similar to that of the coconut mite. In Florida, about $99 \%$ of the microscopically examined damaged coconuts had damage attributable to coconut mites and about $1 \%$ were damaged by Tarsonemus $\mathrm{sp}$. Thus, in field surveys coconut mite damage would rarely be misdiagnosed.

Coconut mites beneath tepals of coconuts subjected to $-1.5^{\circ} \pm 0.5^{\circ} \mathrm{C}$ for 5.5 hours and then kept at $+7^{\circ} \mathrm{C}$ for 72 hours did not appear to be adversely affected by this treatment. All eight coconuts harbored coconut mites. Five of the coconuts harbored colonies of several hundred to thousands of active coconut mites. Coconut mite eggs were of normal turgidity and color.

Of the two groups of $40+$ coconut mite eggs exposed to $-3^{\circ} \mathrm{C}$ for 2.5 and 5 hours, respectively, one egg in each group hatched 2 days after the cold treatment. Seven of $40+$ eggs not subjected to cold treatment hatched. 
About $10 \%$ of the coconut mites on coconuts kept at ca. $5^{\circ} \mathrm{C}$ for 10 days became active within an hour after they were removed from the refrigerator to ca $25^{\circ} \mathrm{C}$.

These simple tests, although inconclusive with regard to the numerical impact of the cold treatments on coconut mite populations in the field, showed that coconut mite populations can survive subfreezing temperatures for at least 5 hours, and can survive more than a week at $5^{\circ} \mathrm{C}$, a temperature that is much cooler than the average winter temperature in southern Florida. From mid-1985 through 1988, during which period coconut mites spread throughout the Miami Coconut Seed Orchard, there were no frosts, but minimum temperatures in Miami fell to $+2^{\circ} \mathrm{C}$ one to several times each year (15).

It has been reported that coconut mite populations increase during wet seasons $(7,9)$. But it has also been suggested, on the basis of geographical or seasonal distribution patterns of the coconut mite in some countries, that the species thrives in dry climates or builds up in the dry season and is not well adapted to rainy climates $(4,8,16)$. Mariau (10) reported that a heavy infestation of coconut mite could be reduced by irrigating the palm plantation, and suggested that during drier periods growth of coconuts is slower; thus young developing tissue is subjected to mite damage for longer periods. Since the annual precipitation on the Florida mainland (ca $1500 \mathrm{~mm}$ ) is about twice that of the Keys, one might suspect that this is the factor which restricts the distribution on the Florida mainland. However, the annual precipitation at Añasco, Puerto Rico, which has a high incidence of coconut mite, is similar to that on the Florida mainland. Thus, we have not identified any environmental factors that would restrict the distribution of coconut mites on the Florida mainland.

When newly detected in some countries, coconut mite-infested palms have been detected simultaneously in several localities. Then the infestation has spread quickly (10). It thus can be hypothesized that in these localities, coconut mites may have been present at low levels and have undergone an explosive population increase in recent years because of unknown ecological factors. Doreste (1) presented this hypothesis to explain the wide distribution of coconut mite in Venezuela when it was first detected there in 1967.

There is evidence that at least in some localities the coconut mite was present long before it was identified and reported in scientific literature. Damage attributable to coconut mite was observed on the Caribbean Coast of Colombia as early as the late 1940s (6) but the mite was not identified from Colombia until the 1970s. Similar damage has been seen in Jamaica for many years (Joe Suah, ministry of Agriculture, Jamacia, personal communications), but only recently has this been reported in the literature (5). In Florida, damage attributable to this mite was ob- 
served on coconuts as early as the 1950s (Curtis Dowling, Florida Department of Agriculture \& Consumer Services, retired, personal communications). The senior author noticed coconuts with damage typical of that caused by coconut mites in Ft. Lauderdale and other Florida localities while conducting research on lethal yellowing beginning in 1976, but did not collect specimens of the mites until 1984. Assuming that the damage observed earlier was not caused by another species (e.g., Tarsonemus $\mathrm{sp}$.), it would be expected that the distribution of the coconut mite on the mainland would be more extensive than it is, unless it is restricted by as yet undetermined environmental factors.

\section{LITERATURE CITED}

1. Doreste, S. E., 1968. El ácaro de la flor del cocotero (Aceria guerreronis Keifer) en Colombia. Agron. Trop. (Maracay) 18: 379-86.

2. Estébanes, M. L., 1978. Ácaros depredadores de Eriophyes guerreronis (Keifer) en la zona de Tecpán de Galeana, Gro., Folia Entomol. Méx. 39-40: 41-42.

3. Estrada, O., J. y M. González A., 1975. Daños causados en coco por Aceria guerreronis, Acarina: Eriophyidae) en Cuba. Rev. Agric. Cuba 8: 30-4.

4. Griffith, R., 1984. The problem of the coconut mite, Eriophyes guerreronis, in the coconut groves of Trinidad and Tobago. Proc. Caribb. Food Crops Soc. 20: $128-32$.

5. Hall, R. A., 1981. The coconut mite, Eriophyes guerreronis, with special reference to the problem in Mexico. Proc. Br. 1981 Crop Prot. Soc. 113-19.

6. Johnson, W. O., 1970. Minimum temperatures in the agricultural areas of peninsular Florida. Summary of 30 winter seasons-1937-67. Univ. IFAS Publ. No. 9.

7. Julia, J. F. and D. Mariau, 1979. Nouvelles recherches en Côte d'Ivoire sur Eriophyes guerreronis (Keifer) acarien ravageur des noix de cocotier. Oleagineux 34 (4): 181-87.

8. Mariau, D., 1969. Aceria guerreronis Keifer: récent ravageur de la cocoteraie dahomeenne. Oleagineux 24: 269-72.

9. Mariau, D. 1977. Aceria (Eriophyes) guerreronis: un important ravageur des cocoteraies africaines et américaines. Oleagineux 32: 101-11.

10. Mariau, D. 1986. Comportement de Eriophyes guerreronis (Keifer) a l'égard de differentes varietés de cocotiers. Oleagineux 41: 499-505.

11. Martyn, E. B., 1949. Notes on a visit to Colombia. Trop. Agric. (Trinidad) 26: 48-50.

12. Medina-Gaud, S. and E. Abreu, 1986. The coconut palm eriophyid mite, Eriophyes guerreronis (Keifer) in Puerto Rico (Acarina: Eriophyidae). J. Agric. Univ. P. R. 70: $223-24$.

13. Mendoza, M., 1988. Empresas Agrícolas de Puerto Rico. Frutales. Depto. Econ. Agric., Univ. P. R., Mayagüez, P.R. pp. 133-61.

14. Moore, D., 1985. Dominica: coconut mite on coconut. FAO Plant Prot. Bull. 33: 119.

15. NOAA 1985-1988, Climatological Data, Florida. Vols. 89-92. National Climatic Data Cent., Asheville, North Carolina.

16. Zuluaga, C. I. and A. Sánchez P., 1971. La rona o escoriación de los frutos de cocotero (Cocos nucifera L.) en Colombia. Oleagineux 26: 767-70. 